\title{
Transatlantica
}

Revue d'études américaines. American Studies Journal

"Window Shopping, Granada, 1930s"

Photographs, p. 16

\section{Mae Claxton}

\section{(2) OpenEdition}

Journals

Electronic version

URL: https://journals.openedition.org/transatlantica/4694

DOI: $10.4000 /$ transatlantica.4694

ISSN: $1765-2766$

\section{Publisher}

Association française d'Etudes Américaines (AFEA)

Electronic reference

Mae Claxton, "'Window Shopping, Granada, 1930s"'”, Transatlantica [Online], 2 | 2009, Online since 02 February 2010, connection on 04 February 2023. URL: http://journals.openedition.org/transatlantica/ 4694 ; DOI: https://doi.org/10.4000/transatlantica.4694

This text was automatically generated on 4 February 2023.

\section{(c) (i) (5)}

Creative Commons - Attribution-NonCommercial-NoDerivatives 4.0 International - CC BY-NC-ND 4.0 https://creativecommons.org/licenses/by-nc-nd/4.0/ 


\title{
"Window Shopping, Granada, 1930s"
}

\author{
Photographs, p. 16
}

\section{Mae Claxton}

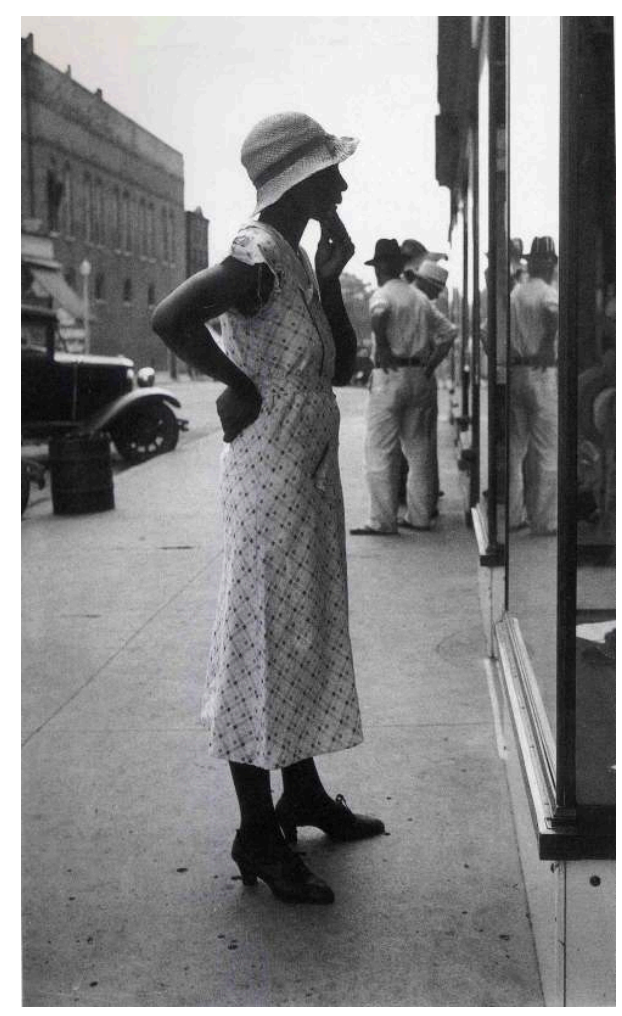

"Window Shopping, Granada, 1930s," Photographs, p. 16, with the gracious permission of the Eudora Welty Foundation

An African American woman, dressed in her Saturday go-to-town-best, stands outside a store window, chin in hand, contemplating the contents in the window. The image is reflective and thoughtful. What is she thinking? And what lies beyond the frame of this photograph? In Mississippi in the 1930s, could she walk into this store, perhaps try on clothes or hats, and make a purchase? If she were welcomed in this store, would she 
have the means to buy the merchandise? The woman is separated from the contents of the store window by the large plate glass of segregation.

2 As in most of her photographs, Welty captures an artistic moment in this image, but the reality of the world outside the frame of the photograph is always present. In this instance, Welty raises questions about this woman as a consumer. How is her ability to buy a mark of freedom conveying access to the American dream? Grace Elizabeth Hale states in her book Making Whiteness: The Culture of Segregation in the South, 1890-1940 that shopping and segregation were uneasily intertwined. Department stores, like railroad cars and movie theaters, were "muddled middle" spaces where segregation remained vulnerable, "neither public nor private, neither black nor white" (9). It was in these "muddled middle" spaces that middle class African Americans chose to shop. While whites and blacks might be separated in schools, churches, restaurants, and other spaces, the ritual of Saturday shopping "belonged to all southerners" (Hale 182). Welty captures this "muddled middle" of a Mississippi small town on Saturday in the group of white men just down the street from the African American woman gazing in the shop window.

Welty took many photographs of store windows. Sometimes the emphasis is on the people looking in, and sometimes the emphasis is on the goods displayed. These images emphasize the visual, staged, performative aspect of shopping, each a kind of stage set of American consumer culture. Hale points out changes in American culture that "emphasized visibility, the act of looking and the authority of the eye-the spectacle" (7-8). In the 1960s, Civil Rights protesters learned to create "spectacles" that drew attention to the inequities of segregation: marches, boycotts, sit-ins, picket lines, freedom rides, and other events that could be broadcast visually to the rest of the nation (293). As Ted Ownby points out in American Dreams in Mississippi: Consumers, Poverty, \& Culture, the Emmett Till tragedy began in a store (151). Hale contrasts spectacle with narrative, stating that "spectacle, the power of looking, was different from narrative, the power of telling. A picture, a representation, could convey contradictions and evoke oppositions [...] more easily and persuasively than a carefully plotted story" (8). Eudora Welty might disagree. In the end, she explains in the preface to One Time, One Place that she "learned quickly enough when to click the shutter, but story-telling required "a long look, a growing contemplation" (12). Both of the arts she pursued, photography and fiction, have much to teach us about the power of looking and the power of telling to achieve change in society.

\section{INDEX}

Subjects: Trans'Arts 
AUTHOR

MAE CLAXTON

Western Carolina University 